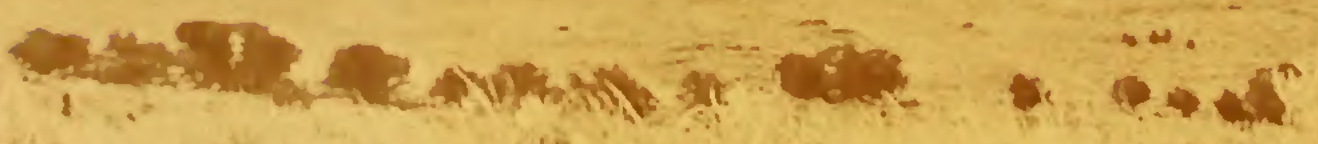

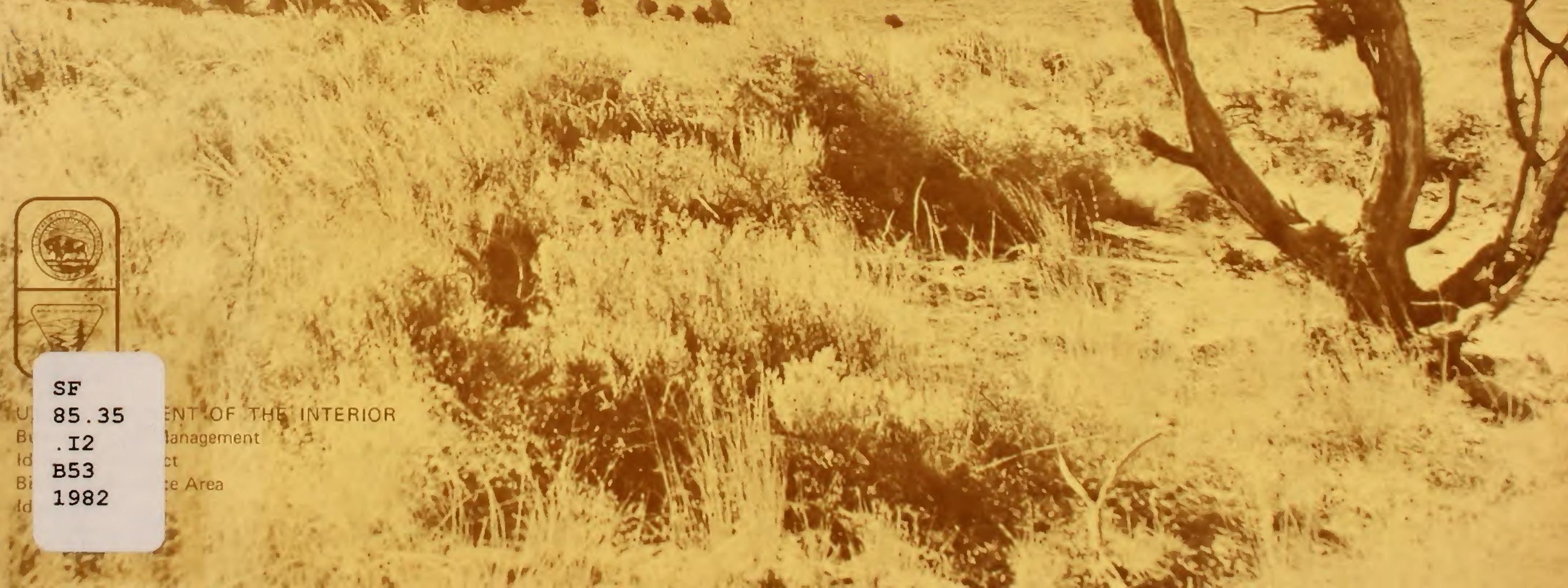




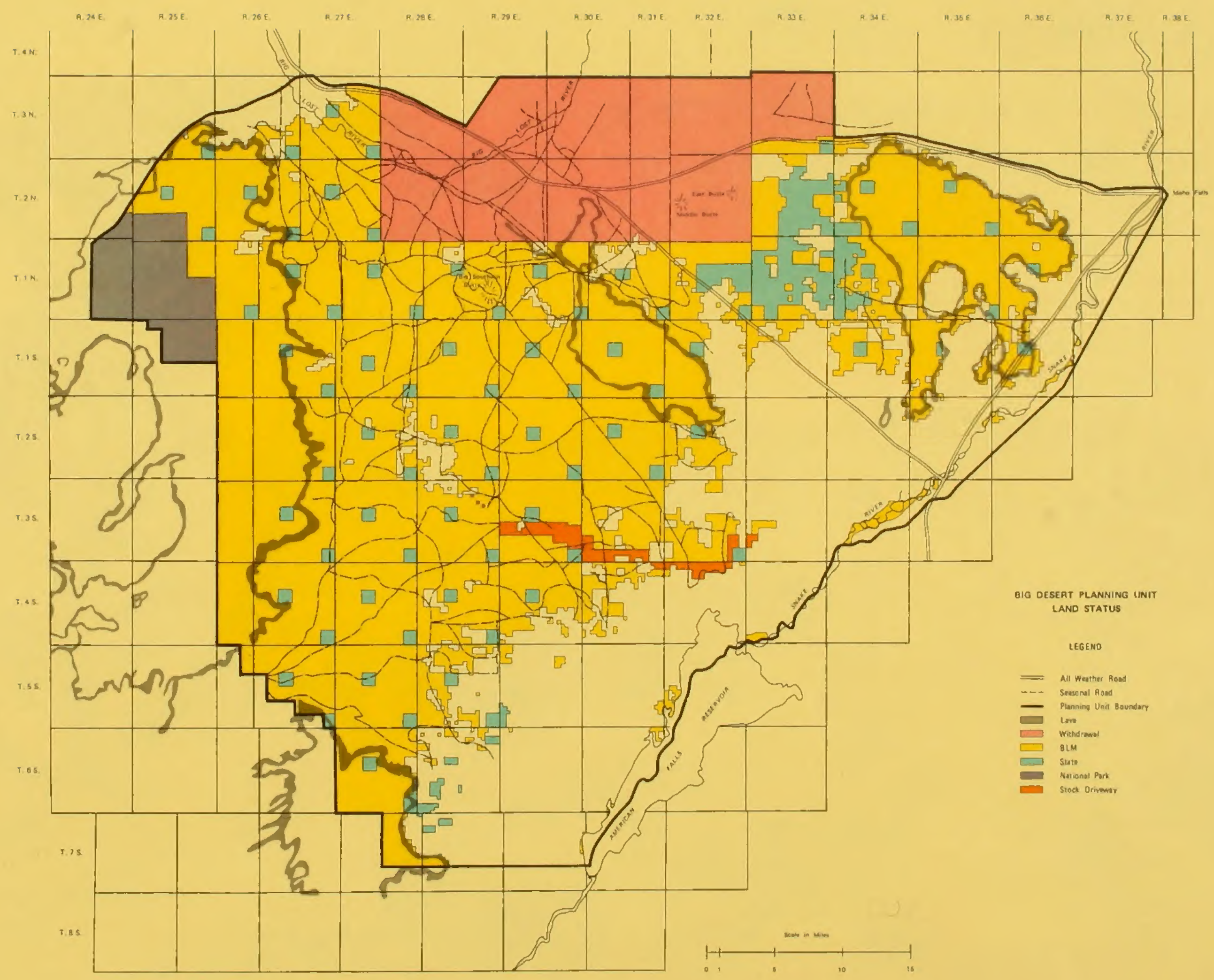




\section{A Word From the District Manager}

This brochure summarizes land use decisions for the Big Desert Management Framework Plan (MFP) and Big Desert Grazing Environmental Impact Statement (EIS).

Because of the large number and complexity of the land use decisions, it is not possible to present all of them here. This document highlights the most significant decisions in each resource program. The document also serves as the Range Program Summary which summarizes the grazing EIS.

You may review the Big Desert plan, EIS and all related documents at the Idaho Falls District Office. My entire staff and I are available to discuss the decisions and help you review the documents. We expect to revise the Big Desert plan from time to time, to meet the people's needs and to cope with changing local and national conditions. Major revisions will be done with full public participation. The range section of this summary will be updated yearly to keep the public aware of progress in the range program and of any management decisions.

Thanks to everyone who assisted in this effort. We look forward to working with you again in the future.

O'dell A. Frandsen

District Manager

Idaho Falls District

May, 1982

\section{TABLE OF CONTENTS}

PAGE NO

A Word From The District Manager . . . . . . . . 1

General Description ................. 2

Major Issues and Problems $\ldots \ldots \ldots \ldots \ldots \ldots \ldots \ldots$

Significant Management Decisions . . . . . . . . . 4

Forest Products $\ldots \ldots \ldots \ldots \ldots \ldots \ldots \ldots \ldots$

Lands ...................... 5

Minerals .................... 6

Range ..................... 8

Public Involvement . . . . . . . . . . 8

Background ................ 8

Alternatives ................ 12

Monitoring .................. 14

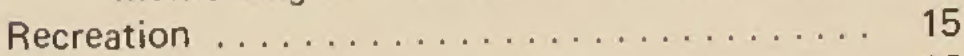

Watershed ....................... 16

Wildlife ..................... 16

Environmental Overview ................. 18

Consultation and Coordination ............ 19

Management Actions $\ldots \ldots \ldots \ldots \ldots \ldots \ldots \ldots 20$

Glossary . . . . . . . . . . . . . . . . . 21

Cover photo: Typical Big Desert range around Cedar Butte.

\author{
BLM Library \\ Denver Federal Center \\ Bldg. 50, OC-521 \\ P.O. Box 25047 \\ Denver, CO 80225
}




\section{General Description}

The Big Desert Planning Unit contains 925,117 acres of public land managed by the Bureau of Land Management (BLM) in Bingham, Bonneville, Blaine, Power and Butte counties. Table 1 shows planning unit acreage by ownership and management responsibility. The Department of Energy acreage represents land within the Idaho National Engineering Laboratory (INEL), a withdrawal for nuclear research and development.

Idaho Falls, Blackfoot, Aberdeen and Arco are the major population centers in the area. The rest of the area is more rural with a less concentrated population.

The public lands lie mainly in one large block interspersed with some State and private lands. There are also small, isolated tracts along the area's east side and about 3,000 acres of public land along the Snake River. The Big Desert public lands are primarily used for livestock grazing, wildlife habitat, watershed and recreation.

The INEL is the major source of area income and employment, followed by agriculture and livestock production.

The Big Desert area has seven major vegetation types: big sage. brush, threetip sagebrush, black sagebrush, unproductive, crested wheatgrass seedings and riparian lands. Yearly precipitation ranges from 8.6 inches at the Aberdeen Experiment Station in the southeast to 16 inches at Craters of the Moon National Monument in the northwest. Elevation varies from 4,350 feet near American Falls to 7,560 feet atop Big Southern Butte.

TABLE 1

Land Ownership in the Big Desert Unit

Land Ownership

Public lands

BLM stock driveway withdrawal

National Park Service

Department of Energy withdrawal

State

Private

TOTAL

\section{Acres}

925,117

1,586

45,316

213,850

84,800

521,318

$1,791,987$ 


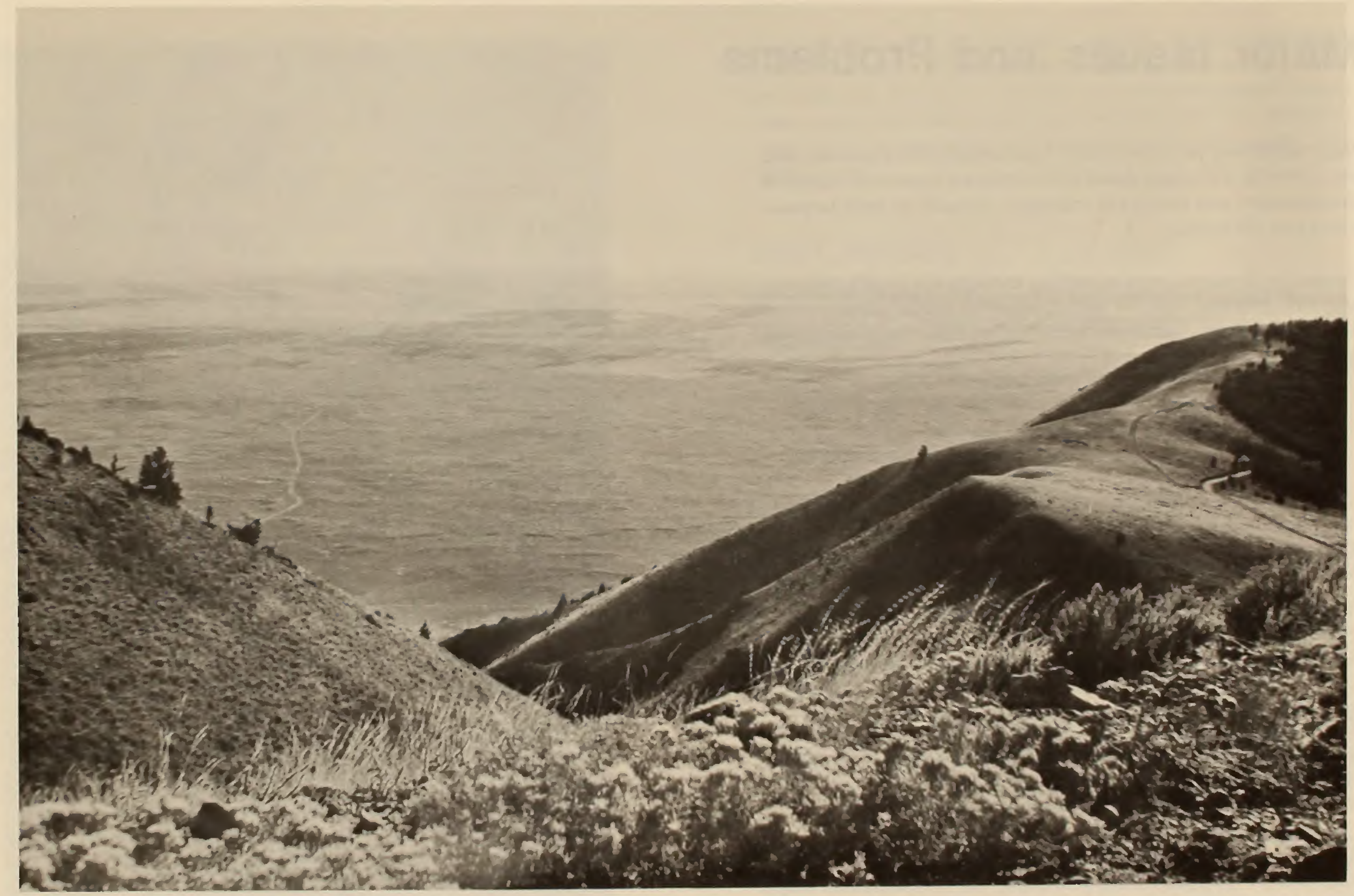

From atop Big Southern Butte, looking southwest. The dark patches in the distance are areas burned during wildfires of the summer of 1981. Other than several buttes, the lack of topographic relief is common in the desert. 


\section{Major Issues and Problems}

Major issues and problems result from present and potential land use conflicts, the unavoidable environmental impacts of resource development, and social and economic impacts on local commu. nities and life styles.

Issues and problems were identified through the BLM's planning and EIS process, both of which involved public participation. The management decisions section describes these issues and problems for each resource.

\section{Significant Management Decisions}

The ultimate basis for management decisions is the capability of the land itself. Accordingly, geology, climate, soils, topography, wildlife and vegetation along with public demand were major considerations in the Big Desert land use decisions.

The following decisions are not all inclusive. If you want to examine the complete set of decisions, you may see them at the Idaho Falls BLM District Office.

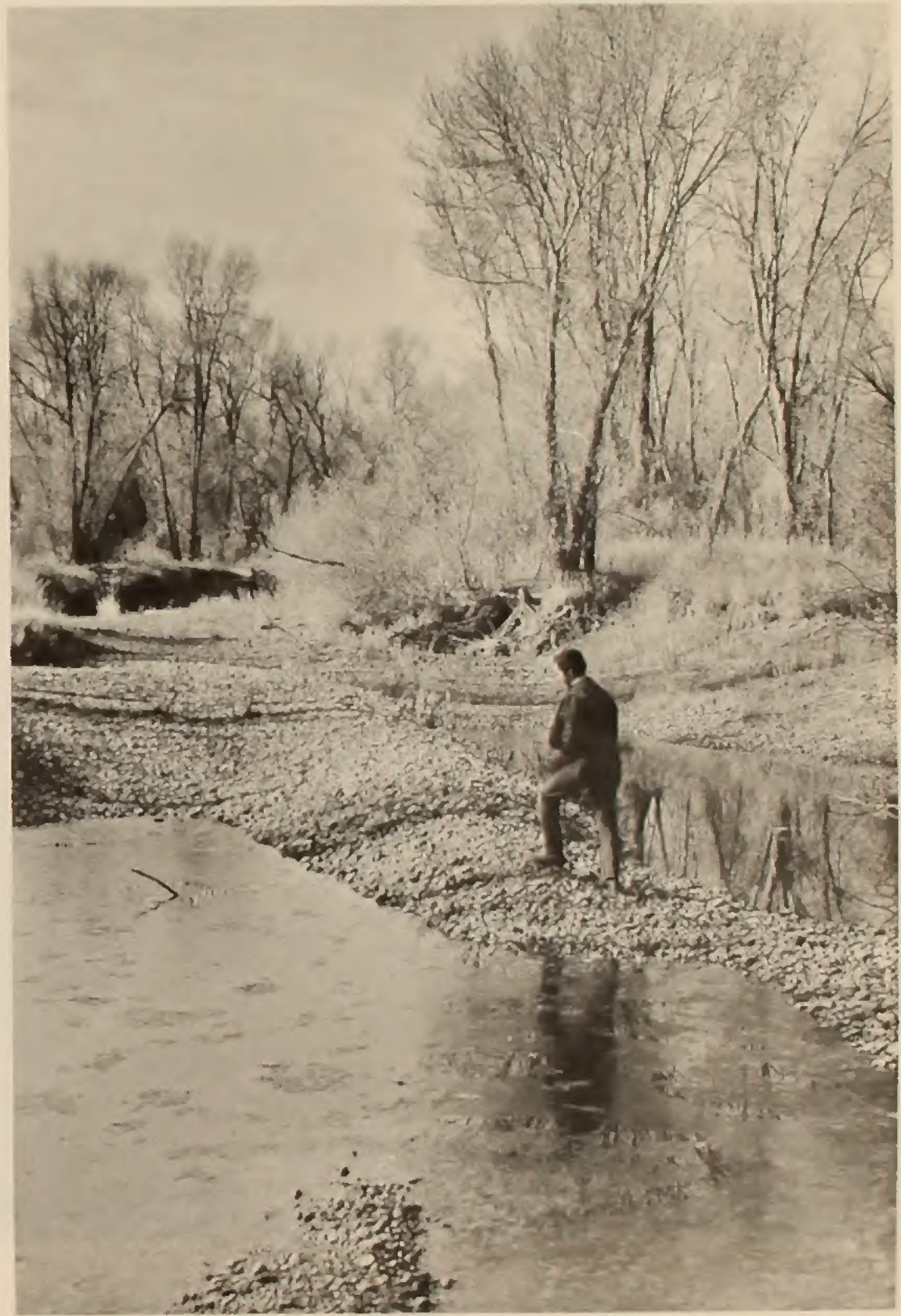

Although cottonwood along the Snake River is part of the unit's forestry resource, its highest value is as wildife habitat 


\section{Forestry Program Summary}

Forested lands in the Big Desert area are located along the Snake River and on Big Southern Butte. Because of severe conditions on the Butte (such as steep slopes, limited access and short seasons), the lodgepole pine and Douglas-fir growing there do not have commercial potential. Cottonwood found along the Snake River is not considered a commercial species now. There are also roughly 300 acres of unproductive juniper woodland on Cedar Butte.

A few small fencepost sales have been made in the juniper woodlands. Firewood sales have been made for cottonwood along the Snake River.

\section{FORESTRY DECISION}

AN INTENSIVE FORESTRY PROGRAM WILL NOT TAKE PLACE WITHIN THE PLANNING UNIT.

The highest value of the Snake River lands is for wildlife habitat; an intensive forestry program would be detrimental to this value. Other forested lands in the unit do not have enough commercial value to justify a forestry program.

\section{Lands Program Summary}

The BLM has surface management responsibilities on about 52 percent of the total Big Desert land area. Another 12 percent lies within the Idaho National Engineering Laboratory (INEL) where the Department of Energy (DOE) has surface management responsibilities. BLM administers livestock grazing, minerals, and lands actions (rights-of-way) under an agreement with DOE on a portion of the INEL.
Much of the work in the lands program involves processing Desert Land Entry applications, reviewing withdrawals such as the INEL and the stock driveway, and reviewing classifications made under the Classification and Multiple Use Act (C\&MU). Other areas of endeavor are access, agricultural trespass, and rights-of-way.

\section{LANDS DECISIONS}

BIG SOUTHERN BUTTE WILL NOT BE DEVELOPED AS A COMMERCIAL COMMUNICATIONS FACILITY.

Another communication site already exists on Jumpoff Peak which has commercial power, an existing building, is higher in elevation, has better access and provides comparable signal coverage.

REVOKE THE MULTIPLE USE CLASSIFICATION AND ALL OF THE RESTRICTIONS IT INCLUDED EXCEPT THOSE UNDER THE AGRICULTURAL LAND LAWS.

One of the main purposes of the C\&MU Act was to ensure retention of some lands in public ownership for multiple use management. This purpose is now covered under the Federal Land Policy and Management Act, which also makes the disposal of public lands discretionary if it is in the national interest. Those lands identified as having agricultural potential will remain classified until the BLM develops activity plans for their possible disposal.

IMPROVE MANAGEMENT OF PUBLIC LANDS BY IMPROVING LAND STATUS PATTERNS THROUGH STATE AND PRIVATE EXCHANGES AND DISPOSAL ACTIONS.

Exchanging or disposing of small, isolated tracts of public land provides better comprehensive management. Opportunities exist where such land actions can benefit the public. 
Big Southern Butte, a National Natural Landmark, will not be developed as a commercial communications facili. ty.

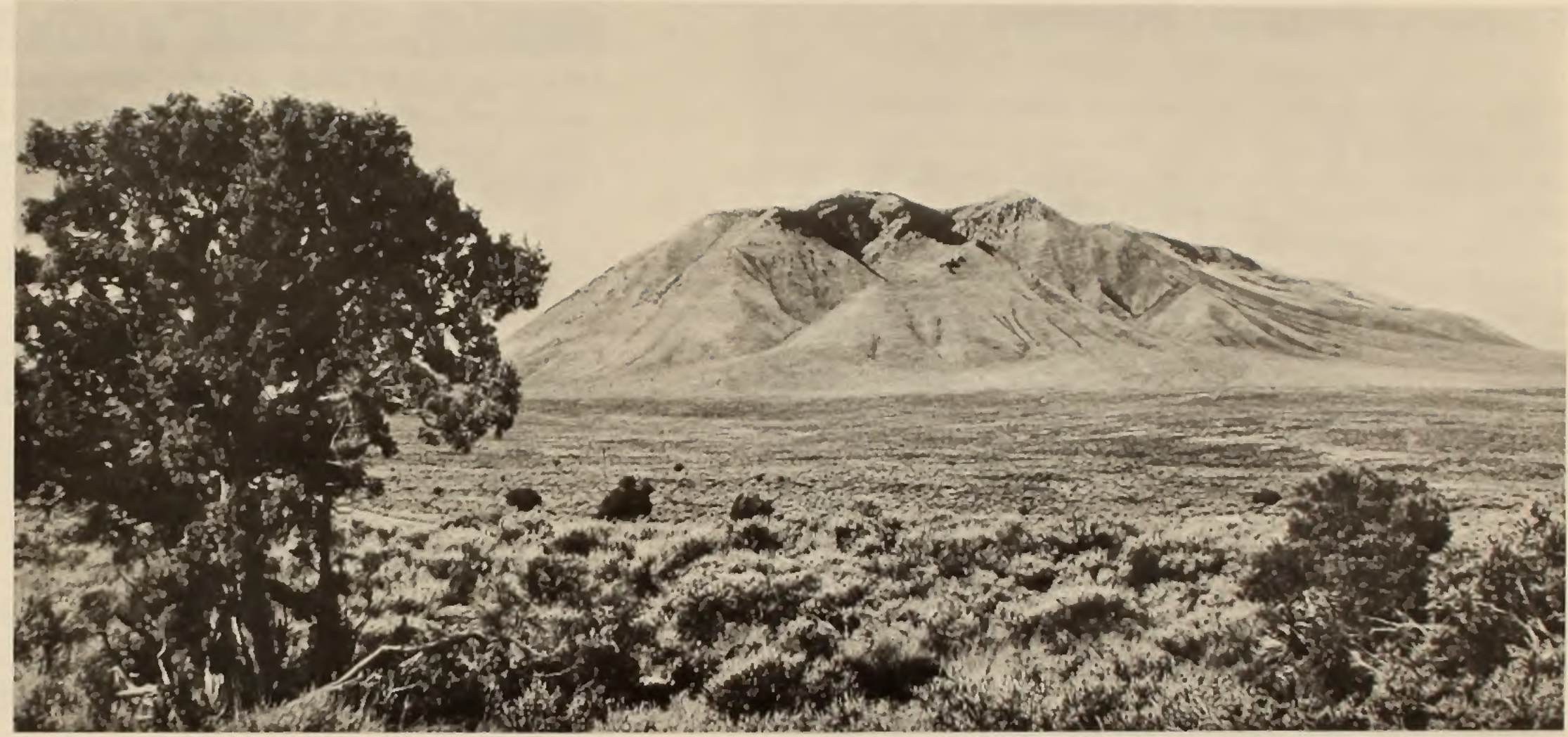

\section{Minerals Program Summary}

The minerals program includes:

1. Disposal of minerals by lease, permit or sale;

2. Coordination of minerals development with other land uses;

3. Assurance of rehabilitation of mined land;

4. Evaluation and processing of mineral patent applications and appraisals.
Mineral activity in the area is confined mainly to saleable min erals such as cinders, gravel, lava rock and fill material. Although the area lies west of the Overthrust Belt, roughiy 190,000 acres are under oil and gas leases and lease applications. No significant exploration or production has occurred on these leases.

Big Southern Butte is covered by mining claims for heavy metals such as gold, silver, lead, and molybdenum. The western portion of the planning unit near Craters of the Moon lava flows has been classified as potentially valuable for geothermal resources by the U.S. Geological Survey. 


\section{MINERALS DECISIONS}

ALLOW EXPLORATION AND LEASING OF MINERALS THROUGHOUT THE ENTIRE PLANNING UNIT.

Other resource values will be protected, where appropriate, by lease or permit stipulations.

ALLOW NO SURFACE OCCUPANCY OF THE FOLLOWING AREAS: SADDLE BUTTE, CHINA CUP, BIG SOUTHERN BUTTE, QUAKING ASPEN BUTTE, AND THE SNAKE RIVER LANDS.

Resource values in these areas warrant protection from surface occupancy and disturbance. Exploration and development could take place through off-site methods such as directional drilling.

LEAVE PUBLIC LANDS OPEN TO MINERAL ENTRY UNDER THE $1 B 72$ MINING LAW. WORK WITH MINING COMPANIES UNDER BLM MINING REGULATIONS TO MITIGATE ADVERSE IMPACTS ON OTHER RESOURCES.

The BLM has very little discretion involving mineral entry under the 1B72 Mining Law, but provisions for protecting other resource values can be made.

KEEP THE ENTIRE AREA OPEN FOR SALEABLE MATERIALS EXCEPT FOR THE FOLLOWING: SNAKE RIVER LANDS, GREAT RIFT, HELL'S HALF ACRE AND CEDAR BUTTE WILDERNESS STUDY AREAS, BIG SOUTHERN BUTTE, KINGS BOWL (CRYSTAL ICE CAVE), CHINA CUP BUTTE, SADDLE BUTTE, OUAKING ASPEN BUTTE, BOX CANYON (BIG LOST RIVER), AND HELL'S HALF ACRE LAVAL FLOW EAST OF $1-15$ IOPEN TO COMPETITIVE

\section{SALES ONLY).}

These locations have other resource values that warrant ex cluding them from mineral sales.

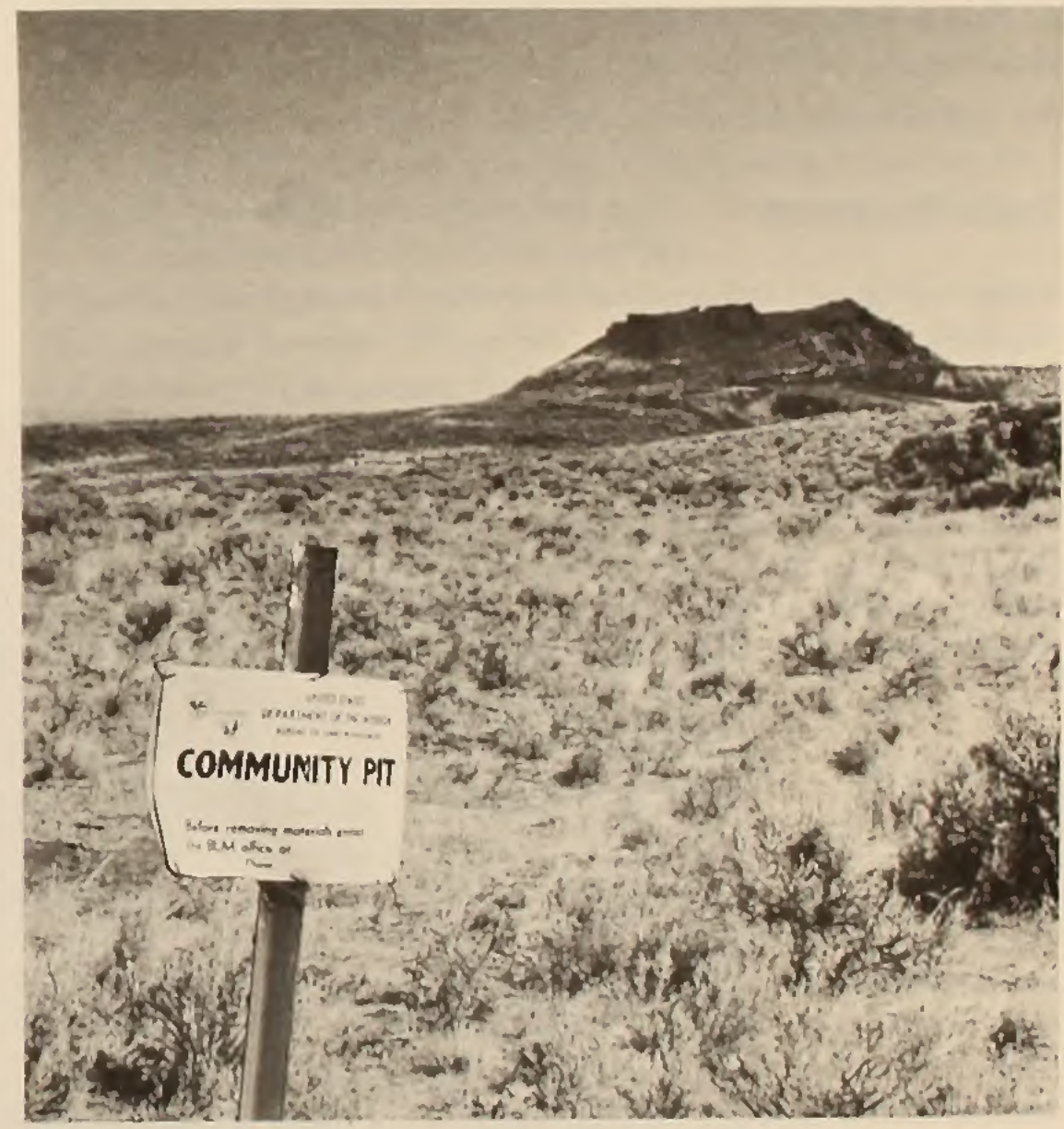

Community cinder pits provide saleable mineral materials, a big part of the area's mineral activity. 


\section{Range Program Summary}

This section summarizes the rangeland management decisions for the Big Desert unit. These decisions are based on multiple use planning and the grazing environmental impact statement. This summary conforms with Title 43, Code of Federal Regulations, Part 4160.1-1(a), Grazing Administration and Trespass on Public Lands. The summary also meets the record of decision requirement of the National Environmental Policy Act of 1969.

\section{Public Involvement}

Many formal and informal public contacts were made during the planning process, and many comments received during those contacts were included in the draft grazing environmental impact statement (EIS) which was released for public review and comment in March, 1981. Significant public comments were also received on the draft EIS, which led to several changes in the final EIS which was released in August, 1981. Additional public contacts will be made as the decisions are implemented and for any major decision changes.

\section{Background}

A total of 562,561 acres of public land and 34,411 acres of withdrawn land on the Idaho National Engineering Laboratory are included in grazing allotments. Seventy livestock operators are licensed to use 25 Section 3 allotments. Seventeen operators have Section 15 leases in 17 allotments along the Snake River. (See the glossary for an explanation of Section 3 and Section 15 leases.) Cattle account for 43 percent of the livestock use, while sheep make up the remaining 57 percent. Active grazing preference on Section 3 allotments is 65,217 AUMs with a 5-year average use of 43,641 AUMs. The active grazing preference on Section 15 allotments is 723 AUMs.
Rangeland condition in the unit is 18 percent good, 48 percent fair, 7 percent poor, 8 percent seeded and 19 percent burned. Estimated trend is less than 1 percent upward, 83 percent static and 16 percent downward.

All of the range is suitable for grazing or can be made suitable by providing water except for 2,998 acres, 735 acres in the Cindercone allotment and 2,263 acres in Big Butte allotment, which are too steep.

\section{RANGELAND DECISIONS}

\section{IMPLEMENT THE MAJOR ELEMENTS DESCRIBED IN} ALTERNATIVE 4 OF THE EIS.

The impacts of all elements in the decision were analyzed and documented in the draft and final EISs. Alternative 4 was chosen over the original Proposed Action because of public comment, and because it was more economically and environmentally acceptable. This preferred alternative provides a desirable balance between resource improvement, resource use, and economic and social conditions. The following section describes the elements in Alternative 4 that will be implemented.

ALLOCATE 60,045 AUMS FOR ACTIVE GRAZING BY LIVESTOCK AND 932 AUMS FOR WILDLIFE.

The vegetation allocation by allotment is shown on Table 2 . Table 3 shows seasons of use and grazing systems. Vegeta. tion will be allocated to livestock, antelope and deer. Unallocated vegetation is available for watershed protection, aesthetics and other nonconsumptive uses. These allocations could allow a 100 percent increase in antelope and deer populations, but water availability is a limiting factor. A 39 percent increase in antelope and an 11 percent increase in sage grouse are projected as a result of planned water developments. 
THE OFFICIAL START OF THE GRAZING SEASON WILL BE EIGHT DAYS TO ABOUT TWO WEEKS LATER THAN AT PRESENT.

Actual turnout dates will be determined by range readiness (see glossary).

THE FOLLOWING PROJECTS ARE NEEDED TO IMPLEMENT THE GRAZING MANAGEMENT PROGRAM: 32 MILES OF FENCE, 24 MILES OF PIPELINE, 3 WELLS, 3 RESERVOIRS, 15 TROUGHS, 4 STORAGE TANKS, 5 MILES OF NEW ROAD, AND 63,600 ACRES OF VEGETATION MANIPULATION (BURNING ON 58,200 ACRES AND PLOWING AND SEEDING ON 5,400 ACRES).
Alternative 4 calls for plowing and seeding 4,800 acres. An additional 600 acres will be plowed and seeded in the River. field allotment to help implement grazing management. This 600 -acre reseeding was not part of Alternative 4. This project and any changes or additions to the above projects will be analyzed through an environmental assessment.

Livestock use would be adjusted over a 5 year period begin ning in 1982 according to the following schedule:

1. Grazing reductions the first year would not exceed 10 percent of the previous year's preference, except in No. 2 Well allotment where the entire 11 percent reduction is being implemented the first year.

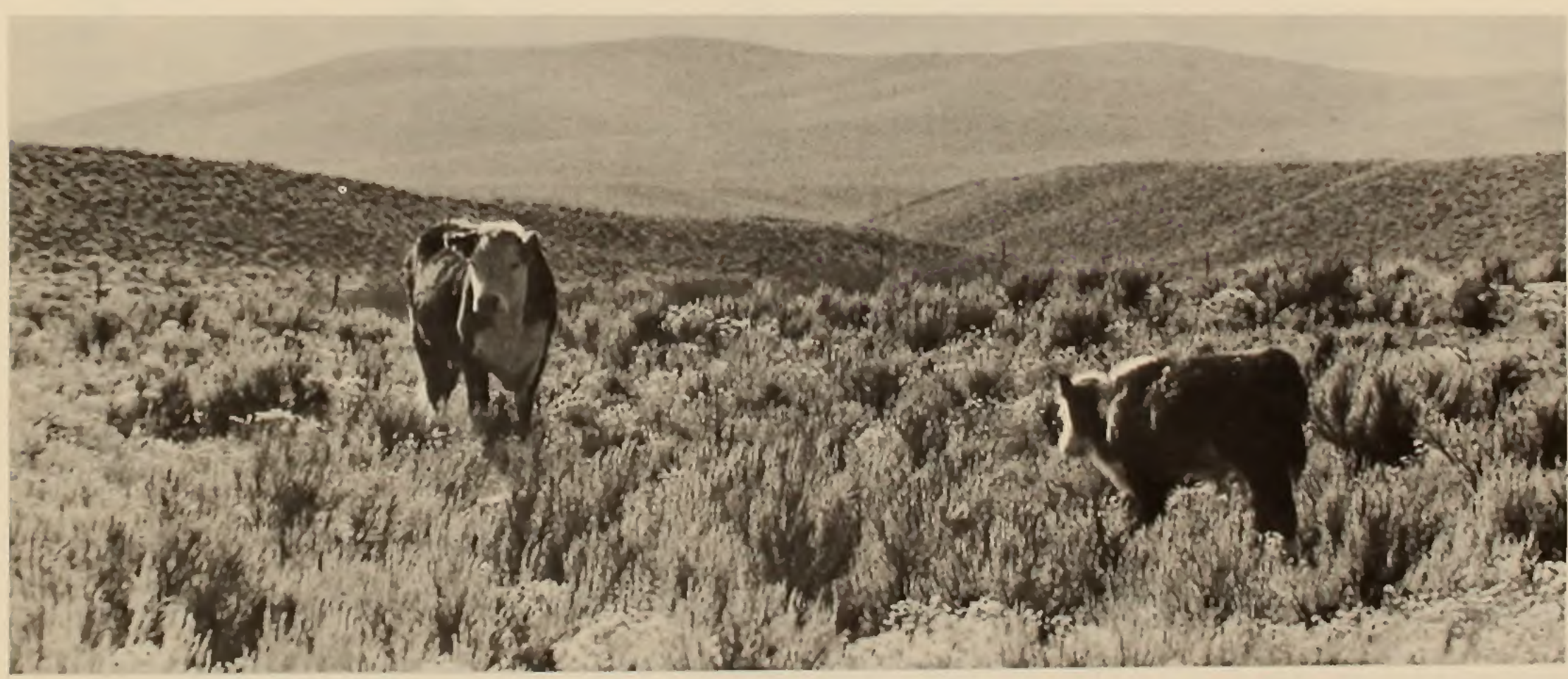

Cattle account for 43 percent of the livestock use in the Big Desert unit. Seventy livestock operators are li. censed in Big Desert allotments. 
TABLE 2

Initial Vegetation Allocation

Alternative 4

Allotment

Antelope AUMs

Deer AUMs

Non-Consumptive AUMS

Total AUMs

AEC Riverfield*
Big Butte
Big Desert
Bowers
Cedar Butte
Cinder Cone
Cox's Well
East Butte
Hell's Half Acre ${ }^{*}$
Houghland
Huddles Hole
Judge
Klempel**
Moonshine
Moreland
Muirbrook *
No. 2 Well
Ouaking Aspen
Riverfield ${ }^{*}$
Rock Corral
Rudeen
Smith
Springfield
Sunset
Webb**

4
60
192
-
20
3
6
1
-
25
-
-
-
4
-
-
24
71
3
3
31
5
56
9
-

9
57
$7 \mathrm{~B}$
-
20
19
22
2
-
26
-
-
-
21
-
-
9
46
6
19
25
20
22
14
-

607

3,414

33,222

20

901

1,020

$1,5 \mathrm{~B} 8$

123

17

2,499

45

8

2B

573

262

2

1,301

5,637

203

1,200

826

2,3B6

2,729

1,322

112

415

60,045

8,220

29,061

104,350

184

7,495

8,726

15,679

896

155

18,081

891

48

236

6,649

5,005

36

12,833

56,059

3,860

6,630

4,351

$15, B 47$

24,238

14,846

279

344,655
8,840

32,592

137,842

204

8,436

9,768

17,295

1,022

172

20,631

936

56

264

7,247

5,267

38

14,167

$61, \mathrm{~B} 13$

4,072

6,852

5,233

18,258

27,045

16,191

391

405,533

* Implementation delayed until after completion of the Big Lost-Mackay Grazing EIS.

** Minor differences exist between these figures and figures in the Big Desert EIS. 
TABLE 3

Section 3 Allotment Summary

Allotment

AEC Riverfield*

8ig Desert

Big Butte

Bowers

Cedar Butte

Cinder Cone

Cox's Well

East 8utte

Hell's Half Acre**

Houghland

Huddles Hole

Judge

Klempel

Moonshine

Moreland

Muirbrook**

No. 2 Well

Quaking Aspen

Riverfield*

Rock Corral

Rudeen

Smith

Springfield

Sunset

Webb $^{* *}$
Federal Acres

16,054
248,783
44,642
320
12,622
12,052
17,344
1,183
250
23,163
652
80
320
6,384
7,469
120
23,896
70,032
8,114
10,752
10,153
20,233
34,546
11,021
760

Season of Use

Grazing System

Livestock Class

$04 / 16-12 / 31$
$04 / 10-06 / 30$ and $10 / 16-02 / 21$
$04 / 21-06 / 30$
$04 / 20-05 / 19$
$04 / 22-06 / 15$ and $11 / 16-01 / 07$
$04 / 08-05 / 31$
$04 / 15-11 / 27$
$06 / 01-10 / 18$
$05 / 01-05 / 31$
$04 / 15-09 / 05$
$05 / 01-08 / 15$
$04 / 01-10 / 01$
$04 / 16-07 / 16$
$06 / 21-08 / 09$
$04 / 15-05 / 15$ and $01 / 05-02 / 05$
$04 / 15-06 / 15$ and $09 / 01-10 / 15$
$04 / 15-06 / 29$
$04 / 21-01 / 31$
$05 / 01-09 / 20$
$04 / 16-05 / 30$
$05 / 01-06 / 15$
$04 / 21-06 / 30$
$04 / 15-06 / 15$
$04 / 21-11 / 20$
$04 / 01-05 / 31$

$\begin{array}{cc}\text { Deferred } & \text { Cattle } \\ \text { Seasonal } & \text { Sheep } \\ \text { Deferred } & \text { Cattle } \\ \text { Seasonal } & \text { Cattle } \\ \text { Seasonal } & \text { Cattle } \\ \text { Deferred } & \text { Cattle } \\ \text { Seasonal } & \text { Cattle } \\ \text { Deferred } & \text { Cattle } \\ \text { Seasonal } & \text { Cattle } \\ \text { Deferred } & \text { Cattle } \\ \text { Seasonal } & \text { Sheep } \\ \text { Seasonal } & \text { Cattle } \\ \text { Seasonal } & \text { Cattle } \\ \text { Deferred } & \text { Cattle } \\ \text { Seasonal } & \text { Sheep } \\ \text { Seasonal } & \text { Cattle } \\ \text { Deferred } & \text { Cattle } \\ \text { Rest Rotation } & \text { Cattle } \\ \text { Deferred } & \text { Cattle } \\ \text { Seasonal } & \text { Sheep } \\ \text { Deferred } & \text { Cattle } \\ \text { Deferred } & \text { Cattle } \\ \text { Deferred } & \text { Cattle } \\ \text { Deferred } & \text { Cattle } \\ \text { Seasonal } & \text { Cattle }\end{array}$

TOTAL $\quad 580,945$

* Adjustments in season of use will be delayed until after completion of the Big Lost-Mackay Grazing EIS.

** Minor differences exist between these dates and dates in the Big Desert EIS. 
This rock reservoir fence was built by the Civilian Conservation Corps to help snow drift and collect in the shallow reservoir to the right. Built in the early 1940s, it is one of the oldest functioning water develop. ments in the desert.

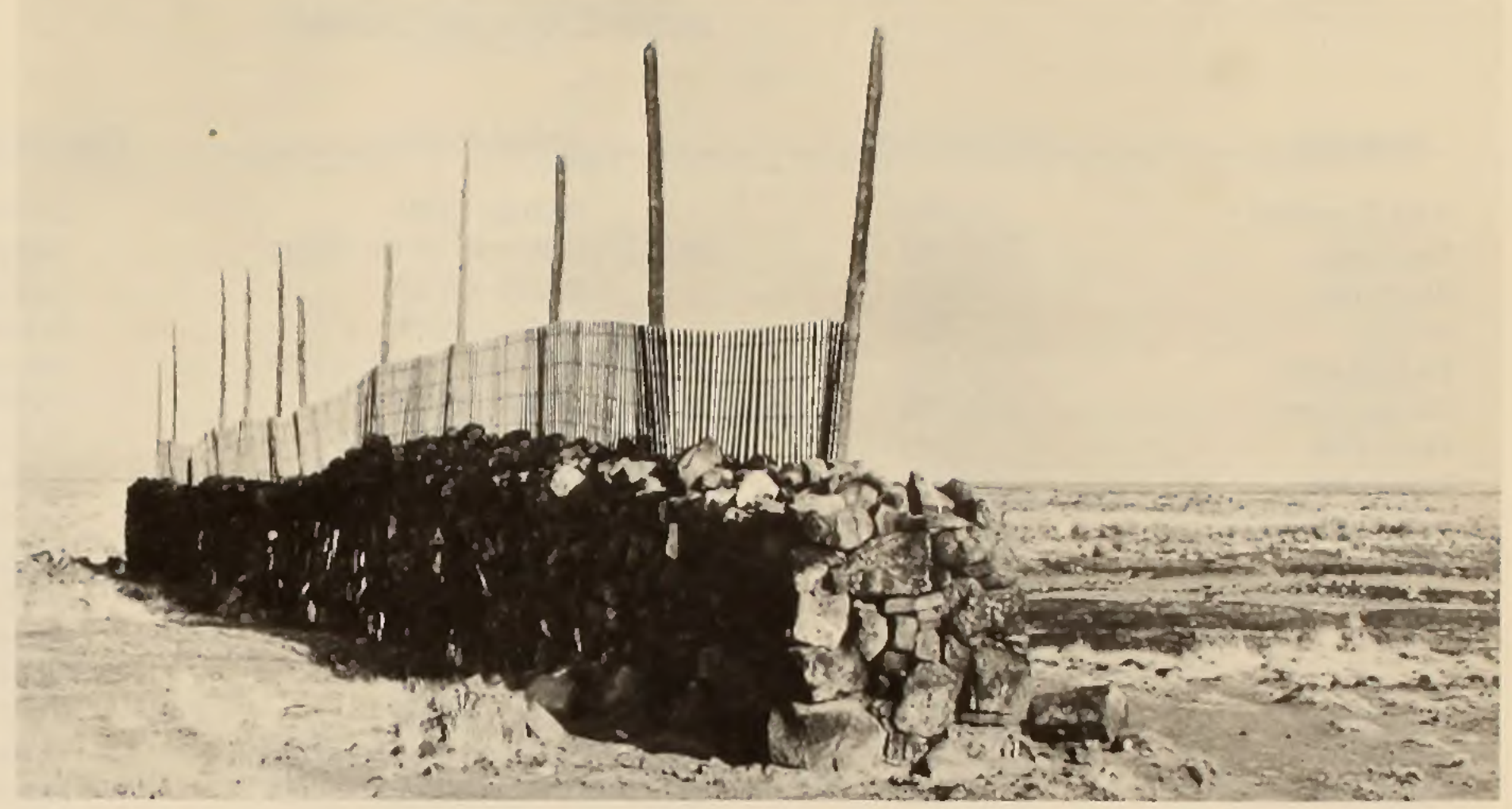

2. The remaining reductions will be divided between the third and fifth years of the reduction schedule. Range condition and forage utilization will be monitored each year to determine if the next reduction needs to be placed in effect.

\section{Impact Summary}

Range condition and trend would improve substantially. Cover is expected to increase, and soil erosion and compaction would decrease. Sufficient forage would be available for present and future wildlife populations. A 39 percent increase in the antelope population and an 11 percent increase for sage grouse are projected. Land treatment would cause significantly less impact than the original Proposed Action.

The number of hunter days would increase by about 10 percent over the next 10 years. Neither ranch consolidations nor capital position (see glossary) would be significantly impacted.

\section{Alternatives}

This section describes the original Proposed Action and the remaining alternatives addressed in the EIS, and the impacts that would have occurred had they been selected. The following summaries are excepts from the final Big Desert EIS. 
Proposed use for the area is to allocate 59,917 AUMs for active grazing use by livestock and 932 AUMs for wildlife (Section 3 only). After 20 years, it is estimated there would be an addition. al 31,766 AUMs that could be allocated to livestock and wildlife. Grazing management proposed for the total 582,989 acres consists of rest rotation grazing on 70,032 acres, deferred rota. tion on 229,425 acres, seasonal grazing on 281,294 acres, and custodial management on 2,238 acres of public land along the Snake River.

The proposed range improvements include 9 wells, 38 miles of pipeline, 36 water troughs, 3 reservoirs, 25 water storage tanks, 82.5 miles of fence, 12 cattleguards and 8 miles of road. The potential exists to control sagebrush on roughly 80,500 acres, of which 10,200 acres could be revegetated with desirable plants. An additional 7,800 acres would be seeded without brush control.

\section{Impact Summary}

Vegetation would improve in quality and quantity, providing increased forage for both livestock and wildlife.

Wildlife habitat condition would remain stable or improve in condition. The availability of water is the limiting factor in the unit; the proposed range management program would improve wild life habitat through increased water availability. Soil erosion would generally decrease and watershed conditions would improve slightly.

The number of hunter days would increase with the increase in wild life populations. Range consolidation and conversion would not be impacted by the original Proposed Action. Capital position would be slighly impacted until sufficient AUMs are re. gained to restore all operators to their current active preferences.
The current livestock grazing program would continue. The active grazing preference would remain at 65,217 AUMs. This alternative assumes that the average annual licensed use for the last 5 years $(43,641$ AUMs) would continue at this level.

No additional project development or land treatment projects for livestock grazing would occur. Project development for other resource activities would continue under present programs.

\section{Impact Summary}

Range condition and vegetation production would show slight improvement. Present erosion and soil compaction would continue. Watershed conditions would not change much from current levels. Wild life distribution and numbers are expected to remain the same.

\section{ALTERNATIVE 2 - NO LIVESTOCK GRAZING}

All livestock grazing on public lands would be eliminated. All existing grazing privileges and cooperative agreements for range improvements would be cancelled. Salvage rights would be granted to range users who had contributed to range management facilities. Use on intermingled State and private lands would be possible if the landowner or lease holder of the State tract were able to fence lands away from public lands. Forage on public lands would be reserved for wildlife and other resource values.

This alternative would have severe impacts on the local livestock industry. As many as $\mathbf{5 0}$ permittees might be expected to sell, consolidate, or convert their ranches to other uses. 


\section{ALTERNATIVE 3 - INCREASE LIVESTOCK USE}

This alternative would implement livestock grazing management without changing existing AUM levels or seasons-of-use. Live. stock would not be limited to any specific utilization levels. Use up to the present active grazing preference of 65,217 AUMs would be allowed. No grazing above this total grazing preference would be authorized until monitoring and studies clearly indicate that additional grazing would be allowed. Grazing systems identified in the original Proposed Action would be implemented in this alternative.

Under this alternative, increased levels of land treatment are proposed. Sagebrush would be controlled through burning, spraying or chaining on 116,086 acres. An additional 36,807 acres would be seeded and receive brush control. These range projects would increase livestock forage production. Project size and species limitations would maximize livestock forage production. Livestock reductions would be made during and following land treatment to ensure adequate rest for plant recovery or establishment.

\section{Impact Summary}

This alternative would have short-term impacts due to grazing beyond the carrying capacity on 15 allotments. Positive impacts to vegetation would occur once land treatments become estab. lished. The long-term annual soil erosion rate would increase. Wildlife populations would be expected to decrease slightly. Opportunities to hunt big and upland game and for wildlife observation would decrease. Neither ranch consolidations or capital position would be impacted.

\section{Monitoring}

Studies and evaluations will follow implementation of each grazing system to see if specific objectives are being met. These studies typically include compiling actual use, range trend, range/watershed condition, utilization, weather data, carrying capacity and wildlife habitat monitoring. Where specific objectives are not being met, adjustments will be made. 


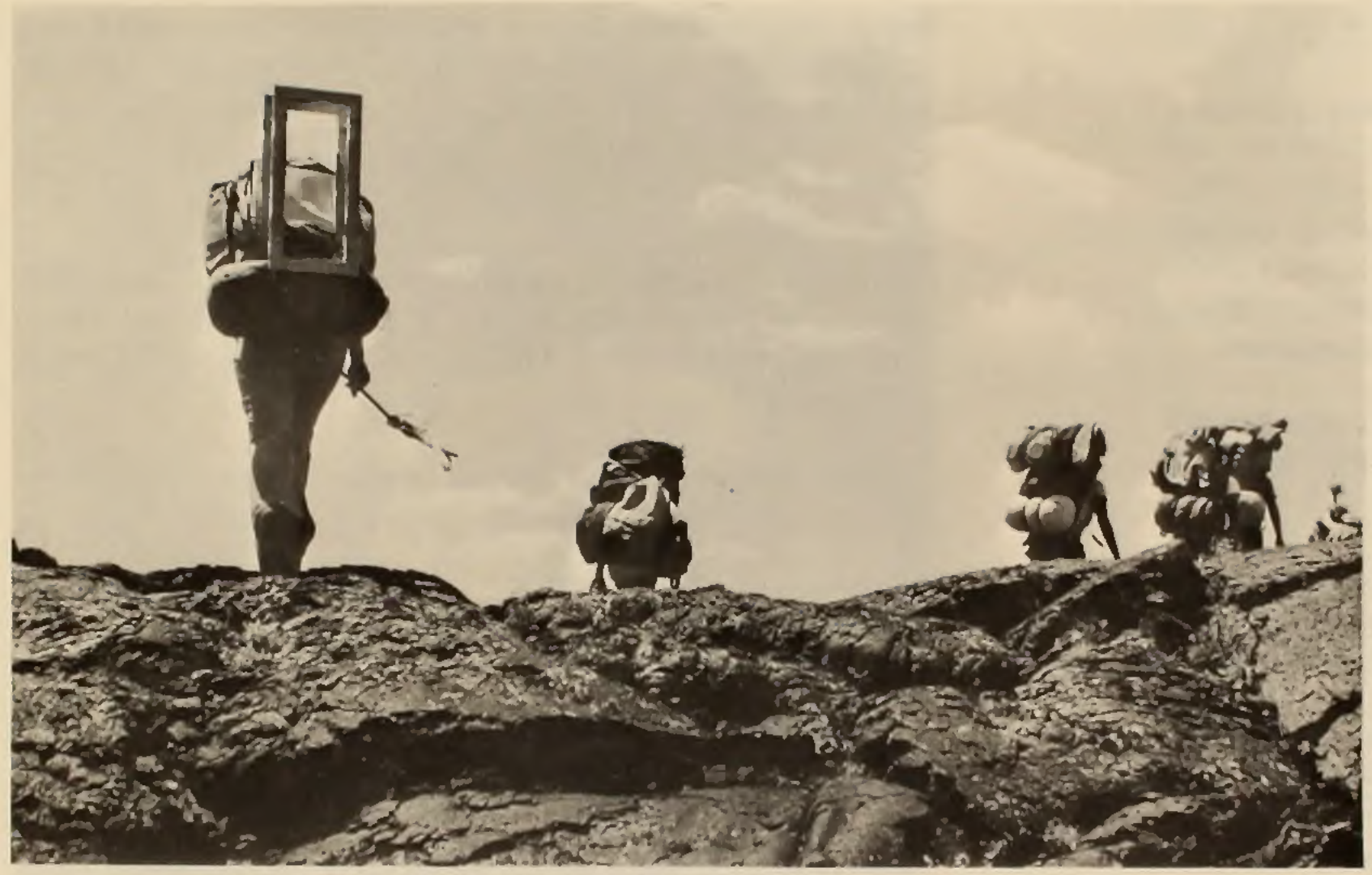

Backpackers hike over lava in the Great Rift, one recreation activity taking place within the Big Desert area.

\section{Recreation Program Summary}

Public lands in the area are important for a variety of recreational activities including hunting, fishing, off-road vehicle use, camping and hang-gliding.

Most recreationists come from population centers along the Snake River in eastern and southern Idaho and from Arco and Atomic City. Visitor use occurs year-round but is concentrated from May through October.
Cultural resource sites in the area that have been accepted in the National Register of Historic Places include Experimental Breed. er Reactor No. 1 (EBR-1, located on Idaho National Engineering Laboratory withdrawal land) and Goodale's Cutoff (Oregon Trail). Big Southern Butte has been designated a National Natural Landmark. The BLM State Director has recommended wilderness designation for the Great Rift, a lava flow adjacent to Craters of the Moon National Monument. 


\section{RECREATION DECISIONS}

DEVELOP A PUBLIC CAMPGROUND AND PICNIC AREA AT THE FIRTH RIVER BOTTOMS.

The Snake River bottom lands near Firth have been and will continue to be used for outdoor recreation activities. Facility development and site management is needed to mitigate existing health, safety and environmental problems.

CLOSE THE FOLLOWING AREAS TO OFF-ROAD VEHICLE USE: CHINA CUP BUTTE, CEDAR BUTTE, SADDLE BUTTE AND BIG SOUTHERN BUTTE.

LIMIT ORV USE TO EXISTING ROADS AND TRAILS ON QUAKING ASPEN BUTTE, AND ON SLOPES GREATER THAN 15 PERCENT.

ALLOW ORV USE ON ALL OTHER PUBLIC LANDS THAT ARE NOT CLOSED OR RESTRICTED.

Some ORV closures and restrictions are necessary to protect natural and cultural values and to prevent erosion on steep slopes.

\section{Watershed Program Summary}

The soils of the lava plains are primarily wind deposits of fine sand and silt. Water erosion is usually not a serious problem, but the soils are quire susceptible to wind erosion. Soil loss is . 2 tons per acre per year in the Big Desert, placing the area in a low ero. sion class. Runoff is mainly from seasonal snowmelt.

Two watersheds have contributed to flooding and sediment damage to local communities: the Twin Buttes watershed near
Tabor, Rockford and Pingree; and the Flat Top watershed near Aberdeen. Watershed improvement and intensive grazing management would not totally prevent local flooding in these areas.

\section{WATERSHED DECISION}

PROTECT AREAS SUSCEPTIBLE TO ACCELERATED EROSION BY IMPLEMENTING GRAZING MANAGEMENT AND BY RESEEDING TO RE-ESTABLISH WATERSHED COVER.

Soil is the most basic resource, and vegetative cover is essential to protect this resource.

\section{Wildlife Program Summary}

The Big Desert area has year-round populations of antelope and deer, although heaviest concentrations of antelope occur during the winter. Sage grouse live throughout the unit year-round.

Threatened and endangered species found in the area include the bald eagle and possibly the peregrine falcon. State sensitive species known to be in the area are the river otter, gyrfalcon, bobcat, ferruginous hawk, long billed curlew, burrowing owl, pigeon hawk, osprey, spotted bat, trumpeter swan and white faced ibis.

Aquatic resources occur along scattered islands and isolated riverbank areas on the Snake River, along the Big Lost River south of Arco, and around American Falls Reservoir.

The highest and best use of the Snake River lands is for waterfowl habitat. All other uses such as livestock grazing will be managed to maintain or improve waterfowl habitat. 


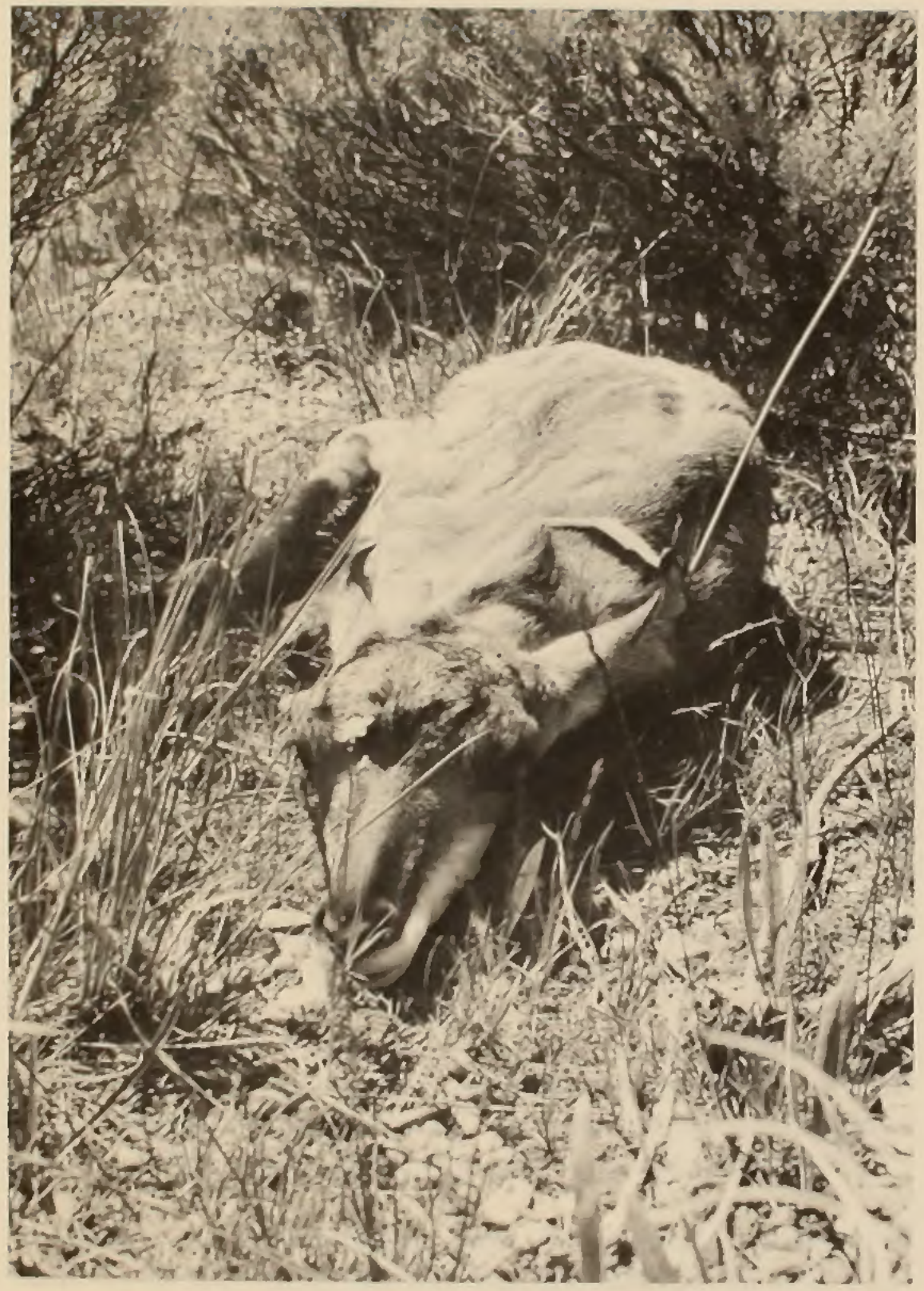

Antelop fawn lies "frozen" in the brush after being radio-collared. The desert's heaviest antelope concentrations occur during the winter.

\section{WILDLIFE DECISIONS}

ALLOCATE FORAGE TO SUPPORT PRESENT NUMBERS OF ANTELOPE AND MULE DEER, AND TO PROVIDE SUFFICIENT FORAGE TO SUPPORT A POTENTIAL 100 PERCENT INCREASE IN POPULATIONS BY 1995.

Water availability, not forage production, is the limiting factor for antelope and mule deer in the Big Desert.

MAINTAIN AND ENHANCE HABITAT TO SUPPORT A 28 PERCENT INCREASE IN THE SAGE GROUSE POPULATION BY 1990.

This would be accomplished through water development. vegetation manipulation and harassment reduction. The habitat is capable of carrying the proposed increase.

THE SNAKE RIVER LANDS WILL BE RETAINED IN PUBLIC OWNERSHIP AND WILL BE MANAGED FOR THEIR WILDLIFE VALUES, PRIMARILY WATERFOWL NESTING.

These lands have been identified for retention in public ownership under a B LM lands determination of October 27. 1968. Wildlife habitat has been identified as the highest value of these lands. 


\section{Environmental Overview}

\section{Forest Products}

There is little forest activity in the area; the environmental impact would be slight.

\section{Lands}

Environmental impacts from lands and realty actions are generally beneficial. Social and economic factors are most often affected by land decisions.

\section{Minerals}

Most of the unit is open to mineral activities under the General Mining Law. There is little mineral activity in the area, and the environmental impact would be slight.

\section{Range}

Livestock forage decisions will maintain or improve vegetation. Improved range condition and forage production will benefit all activities that depend on a sustained yield of quality rangeland vegetation. Maintaining a vigorous and healthy vegetative cover is a sound base for multiple use management of this resource.

\section{Recreation}

Minimal impacts are expected from recreation management decisions. Decisions generally favor environmental protection and present management. The control of surface-disturbing activities will preserve historic values, while the careful location of developments will help maintain a quality visual resource.

\section{Watershed}

Environmentally acceptable management practices, mainly the implementation of grazing systems, will improve watershed conditions by correcting the imbalances of past use. Expected benefits are decreased soil erosion and improved vegetative cover.

\section{Wildlife}

Forage allocated to wildlife is sufficient to support present and projected numbers. The major limiting factor is water availability and distribution. Water development would allow a 39 percent increase in antelope and an 11 percent increase in sage grouse. 


\section{Consultation and Coordination}

Public review was very important in the preparation of the grazing environmental impact statement (EIS) and management framework plan. Throughout the planning process, numerous Federal, State and local agencies, as well as members of the gen. eral public, offered suggestions to improve the plan. The Big Butte Resource Area staff contacted representatives of these groups to ensure that planning efforts and management decisions did not conflict with the land use plans of other agencies. Many significant comments were submitted, and the area manager incorporated a substantial number of those comments in refining and revising the plan.

The Big Desert plan was coordinated with several specific plan ning efforts. County officials were consulted during plan devel. opment and were informed of the final results. Land use deci. sions conform with the land use and zoning requirements of the various counties in which the lands are located.

The BLM's rangeland management policy includes a goal to increase and encourage systematic cooperation, consultation and coordination with rangeland users and owners of lands intermingled with public lands. The policy is an integral part of the land use and grazing management decision-making process. BLM resource area personnel had discussions of proposed grazing decisions with each range user in the Big Desert unit.

Following those discussions, some information surfaced that was not known during the planning and EIS process. The BLM used this information to refine the proposed decisions and improve management. As a result of the consultation process, live- stock AUM figures listed in this document for three allotments differ slightly from AUMs shown in the Big Desert Grazing EIS. Similarly, the season of use in 10 allotments differs slightly from the dates listed in the Big Desert Grazing EIS as a result of user consultation.

Consultation with range users also pointed out a need to handle grazing management on two allotments differently than original. ly proposed. The Riverfield and AEC Riverfield allotments have been treated as separate management units even though there are no fences or other livestock barriers. One allotment is inside the Idaho National Engineering Laboratory withdrawal, and the other lies outside. The two allotments are used in conjunction with a third - the Deadman allotment. The Deadman allotment lies in another planning unit, the Big Lost, where range inventory data are now being complied. For these reasons, it was decided to postpone implementation of decisions in the Riverfield and AEC Riverfield allotments until the Big Lost Grazing EIS has been completed. 


\section{Management Actions}

This plan will be followed by on-the-ground actions. Some decisions in the plan will require more detailed planning before implementing.

Development projects are subject to the requirements of the National Environmental Policy Act. An environmental assess. ment will be prepared for each specific action. If the impacts are unacceptable, the proposed action may be modified or rejected. Some decisions have already been or are being imple. mented.

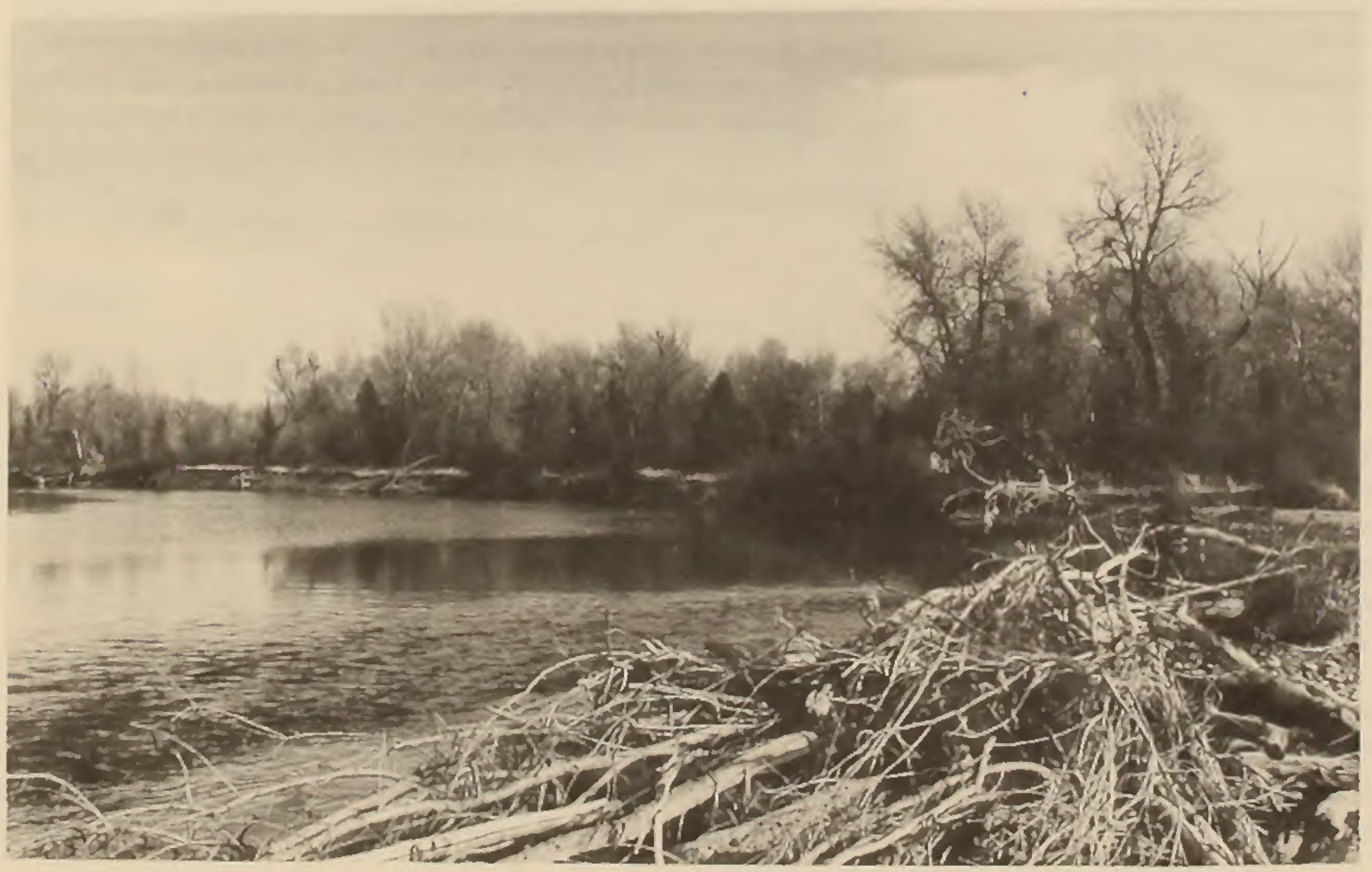

The management decisions will be used in programming and budgeting for the annual work plan. Because on-the-ground actions depend on funding by Congress, it may be some time before some decisions can be implemented.

In response to changing resource conditions and management requirements, this plan will be updated and management decisions revised as new information becomes available. The public will have opportunities to participate in the planning process when major revisions are made.
The Snake River lands will be retained in public ownership and managed for wildlife values. Recreation use of these lands is also high. 


\section{Glossary}

Allotment Management Plan - A detailed plan for intensively managing and improving a specific grazing allotment.

Animal Unit Month (AUM) - The amount of forage needed to sustain one cow or five sheep for one month.

Apparent Trend - A one-time observation of the direction in range condition described as upward, stable or downward.

Capital Position - A financial position based on current capital assets. A change in capital position occurs when the value of capital assets changes.

Carrying Capacity - The maximum stocking rate possible without damaging the vegetation or related resources.

Environmental Impact Statement (EIS) - A document that analyzes the environmental impacts of a proposed action and several alternatives.

Grazing Preference - The maximum number of AUMs that can be grazed on public lands. The grazing preference is attached to private lands owned or controlled by the permittee or lessee.

\section{Grazing Systems:}

Rest Rotation - Grazing is deferred on various parts of an allotment during succeeding years. The deferred parts are allowed complete rest for one or more years.

Deferred Rotation - Changing the time of year when a pasture is grazed. Use in one pasture is rotated between use in other pastures. This provides each pasture periodic rest during some part of the grazing season.
Seasonal - Grazing is restricted to a specific season.

Management Framework Plan - The MFP is the BLM's land use plan. MFP Step 1 consists of sets of recommendations designed to maximize a single resource. MFP Step 2 considers conflicts in use and social, economic and environmental impacts in sets of recommendations by resource for overall multiple use management. MFP Step 3, which considers all comments and experience gained through the EIS process, includes land use decisions for future multiple use management.

Planning Unit - A portion of a resource area for which inventories and land use plans are developed.

Public Lands - Lands administered by the Bureau of Land Management for multiple uses.

Range Readiness - The stage of plant growth at which grazing may begin (under a specific management plan) without permanent damage to vegetation or soil.

Riparian - Pertaining to or situated on the banks of a river or other body of water. Riparian vegetation is the vegetation found along a river or other body of water.

Section 3 and 15 Leases - A Section 3 lease refers to grazing administration on public lands under Section 3 of the Taylor Grazing Act for lands that were originally within grazing districts. Section 15 leases were under Section 15 of the Act for lands that were originally scattered tracts outside of grazing districts. 
